\title{
ULLA RHEDIN, OSKAR K. OCH LENA ERIKSSON (RED.) EN FANFAR FÖR BILDERBOKEN!
}

Stockholm: Alfabeta, 2013 (200 s.)

En fanfar för bilderboken! är ett manifest i kaffebordsformat, med inbjudande illustrationer av tongivande nordiska och internationella bilderboksnamn som Stian Hole, Kitty Crowther, Isol, Svein Nyhus, Dorte Karrebæck, Gunna Grähs, Eva Lindström med flera. Många bilderboksberättare medverkar också i antologin med "strötankar" där de beskriver sina bilderböckers tillkomsthistoria eller reflekterar över tendenser i samtidsbilderboken. Som sådant är detta nordiska grupparbete kring bilderboken i digitaliseringens era, orkestrerat av Ulla Rhedin, Oskar K och Lena Eriksson, ett välkommet tilltag. Vad som eftersöks är ett förnyat angreppssätt på bilderboken i sin helhet.

Sitt nav har projektet kring nestor och eldsjäl Ulla Rhedin samt i kretsen kring Nordiska akvarellmuseet. De kallar sig Fanfargruppen och deras manifest blandar populärvetenskapligt hållna artiklar, processbeskrivningar från verkstadsgolvet och reflektioner kring bilderbokens väsen. Denna kör av röster vill samstämmigt öppna för en mångsidig behandling av bilderboken för att åstadkomma rikare läsupplevelser. Den tilltalande formgivna antologin med sina generösa illustrationer och luftigt lättillgänglig text är helt klart tänkt att nå många.

Ulla Rhedin står för de artiklar som vetter mot en vetenskaplig diskussion kring bilderboken. Hon utgår från den grundsyn hon etablerat på bilderboken i avhandlingen Bilderboken. På väg mot en teori (1992, 2001) och i Bilderbokens hemligheter (2004). Det gör hon bland annat genom kategorier som den genuina bilderboken, ett begrepp som väckt en del polemik i fältet, samt begreppet det konsekventa barnperspektivet. Rhedins kungstanke är att det litteraturvetenskapliga studiet av bilderboken är otillräckligt, men att inte heller ett konstvetenskapligt perspektiv löser dilemmat. Istället är interartiella studier av bilderboken som en performativ konstart svaret på behovet av en förnyad syn på bilderboken. Dessvärre går Rhedin inte alls i dia- 
log med tidigare svensk bilderboksforskning. Tvärtom avfärdas den korthugget som "formalistisk lingvistisk/semiotisk/narratologisk". Därmed mörkas en stor del av den förnyelse bilderboksforskningen under senare decennier genomgått tack vare namnkunniga och dynamiska bilderboksforskare som Kristin Hallberg, Boel Westin, Maria Nikolajeva och Elina Druker, för att bara nämna några.

Avstampet är alltså polemiskt så det rungar om det, som sig bör $i$ ett manifest. Bilderboksavantgardet får här röst, sekunderade av Rhedins strävan efter att förnya begreppsapparaten kring bilderboken. Eller som hon uttrycker det, "att flytta in bilderboken i sitt tidssammanhang". Den energi och vitalisering av bilderboksfältet som Rhedin bidragit med är betydande. Konsekvent har hon pläderat för att vända på perspektivet och tagit bildens parti samt resonerat kring bildberättande och bildsättning på stimulerande sätt. Nu förespråkar hon ett byte av teoretisk hemvist för hela bilderbokskategorin men förankrar dessvärre inte tilltaget i pågående bilderboksforskning. En sådan förankring hade kunnat erbjuda en solid grund för att problematisera bilderbokens särart och de metoder som ständigt behöver förfinas för att bilderboken ska komma till sin rätt. Både bilderbokskritik och högläsning får varsitt antologiavsnitt där förnyande grepp föreslås. Då det gäller bilderbokskritiken exemplifierar Rhedin med Lilla hjärtat-debatten om hur det är möjligt att skildra ett mörkhyat barn utan att hemfalla till hierarkiska stereotyper. Hon menar att de som deltog i debatten inte var bildkunniga nog, vilket är ett lösryckt omdöme som inte leds i bevis. Tvärtom uttalade sig bilderboksexperter som exempelvis Elina Druker i sammanhanget.

Fanfarantologin vänder och vrider på vad bilderboksberättande egentligen går ut på. Huvudbegreppet antologin föreslår är "svävning". Begreppet avser en sömlös förening mellan text-bild-bok, något som skapar ett självständigt, "närmast alkemiskt tredje", som kännetecknas av en "verksam synergieffekt". Ur forskningssynvinkel är svävning ett problematiskt begrepp eftersom det svårligen förmår ringa in den effekt som anses uppstå i en "genuin" bilderboksberättelse. Mer förbryllande är hur detta begrepp egentligen skiljer sig från det etablerade begreppet ikonotext, myntat av Kristin Hallberg. Vad tillför svävning som ikonotext missar? Eftersom Rhedin inte går i dialog med tidigare forskning saknas svar på denna brännande fråga. Ett annat, lika otydligt, begrepp som lanseras är "bilderbokisering", som, i analogi med begreppet filmatisering, står för överförandet till bilderboksform.

Rhedins avsnitt om det konsekventa barnperspektivet diskuterar också barndomens mörker och pläderar för en bredare syn på barn 
och barndom där även existentiella svårigheter får plats. Förtjänstfullt diskuteras hur litteraturen har hävdat barnets annanhet samt hur "nallegillarförväntningar" (med Aase Bergs uttryck, som avser överdådet av antropomorfa karaktärer i bilderboken som förmodas attrahera barnläsaren genom sin gullighet och dråplighet) styr in på en olycklig syn på barnadressatens särskildhet.

Förutom Rhedins inlägg, som dominerar boken, bidrar norska Gro Dahle och berättar om arbetet med Den Arge samt om bilderboken som lekplats. Danska Oskar K och Dorte Karrebæck skildrar sitt samarbete och sin grundsyn på bilderboken. Gunna Grähs, känd för att gärna formulera bilderbokens särskilda poetik med tyngdpunkt på illustratörens eller bildberättarens roll, skriver om barnlogiska språng, barnasinne och barnperspektiv. "Intellektuellt motlut" kallar hon fyndigt illustratörens många gånger otacksamma roll. Här bjuds läsaren också på storyboards, dramaturgiska reflektioner och en rad gäckade frågor.

En fanfar för bilderboken! vittnar om Ulla Rhedins insatser inom bilderboksfältet som djupt fältförankrade och -allierade, det vill säga hon samarbetar tätt med verksamma bilderbokskonstnärer samt strävar efter att nå ut brett med sina begrepp. I manifestets form, med avantgardet av bilderboksmakare som står i bredd, blir antologin en färgstark läsupplevelse som riktar sig till många men som hade vunnit på en tydligare dialog med forskningsfältet. Antologin är både uppslagsrik och utmanande, den väcker mothugg och ger matsäck både åt litteraturforskaren, kritikern, pedagogen och vanliga bilderboksläsare. Den utmynnar i det som var dess startskott, nämligen den finska nestorn inom bilderboksforskning, Maria Laukkas, manifest med femton punkter som är avgörande för bilderboksforskningen och för synen på bilderboken. Manifestets sista punkt uppmanar oss att ständigt, inför varje ny bilderbok vi möter, fråga oss: " Är denna bilderbok nödvändig?"

Mia Österlund

Docent i litteraturvetenskap

Åbo Akademi 